\title{
ASSESSING COMPLIENCE WITH CORPORATE GOVERNANCE PRINCIPLES IN CASE OF ROMANIAN FINANCIAL INVESTMENT COMPANIES
}

\author{
Tatiana Dănescu ${ }^{l}$ \\ Ovidiu Spătăcean ${ }^{2}$
}

\begin{abstract}
Corporate governance includes structures that combine relationships between parties who invest resources and persons that monitor and manage businesses. These relationships are both formal, defined by rules and regulations and informal, materialized in business practices or ethical codes. The paper intends to assess the compliance level with corporate governance principles in case of Financial Investment Companies as institutional investors traded on Romanian capital market (Bucharest Stock Exchange). The research methodology mainly consists in processing data obtained from questioners addressed to these investment companies as well as observing corporate governance statements issued by each of these entities. As presented in the conclusion section, the authors reached valuable conclusions regarding a satisfactory compliance level with corporate governance requirements that apply to Financial Investment Companies.
\end{abstract}

Key words: Financial Investment Companies, corporate governance, principles, ethical codes, regulations

JEL codes: $M 42, M 14$

\section{Introduction}

Successful implementation of corporate governance principles and requirements depends on the degree of reliability and trust allocated to corporate entities, provided that cooperation and responsibility are being required. In current business environment, corporate governance has become necessary since it ensures a certain level of trust required for a properly functioning market economy (OECD Corporate Governance Principles, 2004), reducing information risk and cost of capital and an efficient use of resources. Under this approach, transparencies in relation with investors, as well as the quality of financial reports submitted, reflect primordial factors that can significantly influence the decision to assume a certain level of risk associated with financial investments (Danescu \& Spatacean, 2008).

The importance of corporate governance principles and rules that are being required for Financial Investment Companies has been consolidated through specific regulations, inspired both from the national law (Company Law, Accounting Regulations, Capital Market Law, Regulations issued by the National Securities Commission) and international law (European Directives, Corporate Governance Codes, OECD Principles, etc.). Disclosure and presentation of adequate information related to Financial Investment Companies are considered both relevant tools for monitoring management, as well as significant factors that may strongly influence the evolution of stock market prices. Under the circumstances in which investors have no or little confidence in financial reporting process or non-financial disclosures, they will seek alternative investments.

The paper's main research objective is to identify the compliance level of current Financial Investment Companies' practices with corporate governance principles established in Bucharest Stock Exchange (BSE) Corporate Governance Code. For this purpose, a special interest is

\footnotetext{
${ }^{1}$ Petru Maior University 1, Targu Mures, Romania,e-mail: tatiana_danescu@yahoo.com

${ }^{2}$ Petru Maior University 1, Targu Mures, Romania, e-mail : spatacean_ioanovidiu@yahoo.com
} 
designated for identifying and assessing deficiencies or inaccuracies related to corporate governance implementation process, that are inconsistent with a healthy financial or non-financial communication with stakeholders (qualitative assessment). The assessment of overall compliance level for each Financial Investment Company shall be performed by using a comparative approach on a scoring based method (quantitative assessment), in order to emphasize relevant strengths and weaknesses associated with the process of implementing corporate governance principles within these entities.

\section{Literature review}

Corporate governance is subject for discussion not only for each entity, but also in a general financial market context. There is no certain model for corporate governance for the purpose of increasing financial market's integrity. Nevertheless, there is a consensus even stronger surrounding some governance principles: fair treatment of shareholders, transparency and responsibility associated to the entire decisional process (Dragomir, 2010:49). Protection of shareholders' rights is the most important principle and its implementation is verified through shareholders' involvement in the decisional process, voting rights and exercising manner, acquiring or losing control upon corporation through capital market (Onofrei, 2009: 119).

Bad quality corporate governance practices, lack of understanding the values of a good corporate governance and, sometimes, a fragile institutional framework were significant impediments for the development of efficient capital markets and the establishment of a solid investment climate ins South-East Europe (Morariu et al., 2008:190). In Romania, the market operator Bucharest Stock Exchange has issued the Corporate Governance Code for the purpose to reflect adequate corporate governance principles addressed to companies that have issued financial instruments traded on a regulated capital market, encouraging other companies to adhere to these corporate values. Concerning Financial Investment Companies, the main issues that should capture interest on behalf of internal audit and Audit Committee regarding the proper implementation and application of corporate governance principles and rules, can be described as follows:

a. Ensure an adequate framework for effective corporate governance

Corporate governance should promote transparent and efficient markets and induce the need to obey rules and regulations, by setting clear responsibilities between the regulators and market operators. In this approach, Financial Investment Companies must adopt clear and transparent corporate governance structures, by establishing appropriate functions, competences and responsibilities for management and Board of Directors. Moreover, in the Annual Report, Financial Investment Companies must insert special paragraphs to describe relevant events relating to corporate governance, as well as explanations for inadequate implementation of the recommendations provided by the Corporate Governance.

Transparent relationship between securities issuers and investors constitutes a fundamental requirement for effective promotion of an adequate informational efficiency level for the Romanian capital market. Therefore, specific laws or regulations ${ }^{3}$ require Financial Investment Companies to meet the informational needs of investors by reporting upon issues such are:

- inside information regarding: decisions issued by the Board of Directors to call General Shareholders' Meeting, changes in control positions or management structures, new auditors' approval, termination of commercial contracts that caused a decline in revenue at least by $10 \%$, changes in the rights attached to securities, litigation events or insolvency proceedings initiation, off-balance sheet operations with a significant impact on the financial position.

\footnotetext{
${ }^{3}$ Capital Market Law 297/2004, NSC Regulation no. 1/2006 regarding issuers and securities operations, NSC Regulation no. 15/2004 regarding the authorization and operation of investment management companies, collective investment funds and custodians.
} 
- major events that could cause relevant changes in share price: debt that generates a deterioration of financial position, disposals or acquisitions of assets worth at least $10 \%$ of total assets, contracts of at least $10 \%$ of annual turnover.

- financial position and performances: include interim and annual financial reports, Board of Directors' reports, audit reports or review reports.

- special situations: additional reports prepared by internal auditors or financial auditors at request of shareholders who own at least $5 \%$ of share capital or voting rights.

b. Shareholders' rights and the main features of the property

Given the minimal control that shareholders must have upon current company's operations, it is important that they should be provided sufficient opportunity to protect their investments (Anand, 2007:30). Consequently, corporate governance structures should protect and facilitate the exercise of shareholders' rights, through accurate policies regarding:

- methods for safe keeping of securities and transfer operations involved;

- regular and operative disclosures on relevant information concerning corporate events that influence Financial Investment Companies' operating activities;

- free voting access for all shareholders entitled to attend the General Shareholders' Meeting;

- transparent prices and fair treatment to all shareholders, in order to increase market efficiency and to protect investors' rights;

- clear communication with investors, especially institutional ones concerning fundamental rights and prevention of market abuse.

It is worth mentioning the catalyst role that institutional investors hold in monitoring the adoption and implementation of corporate governance principles and recommendations, driving the market regulators to impose the capital rules for listed companies (Lutgart, 2002:1). This statement is reinforced by the opinions of other authors (Solomon \& Solomon, 2004:89) who believe that institutional investors constitute another powerful mechanism of corporate governance that can monitor the company's management, because their influence can be significant and can be used to align the management interests with those of shareholders. Some studies (Hellman, 2005:317) suggest that institutional investors rather keep a financial approach on investments and are not actively involved in corporate governance implemented by companies in which they invest, in order to make direct requests for specific changes. However, those institutional investors who had the ambition to participate in corporate governance processes are those who adopt a targeted approach to corporate information, because they generally own significant holdings that can not be alienated without major repercussions on the market price.

c. Equitable treatment for shareholders and effective communication

Corporate governance structures must ensure equal treatment of all stockholders, even the minority. From this perspective:

- all investors should benefit from fair treatment regarding disclosures of rights attached to all categories of financial instruments, before acquisition. All changes in voting rights should be subject to approval by the shareholders, including those unfavorable affected.

- minority shareholders should benefit from adequate protection against abusive actions and from effective measures to recover any potential losses. Mainly, these measures include:

$\checkmark$ the right to "exit the company" as a result of a public purchase offer or a merger against the will of minority shareholders;

$\checkmark$ the right to express a cumulative vote at the request of significant shareholders, to elect the members in the Board of Directors. 
- inside trading and abusive individual business operations should be prohibited. Board members and other relevant persons in charge with corporate governance should disclose any material interest in any transaction affecting the Financial Investment Companies ${ }^{4}$.

$d$. The role of securities holders within corporate governance system

Corporate governance structures should recognize shareholders' fundamental rights, as they are set by law or other common practices, promoting active cooperation between Financial Investment Companies in establishing a climate of welfare and supporting the national economy from a financial standpoint.

\section{e. Disclosure and transparency}

Corporate governance structures must ensure proper and prompt dissemination of all significant issues relating to Financial Investment Companies, including financial statements, ownership and governance policies. Both dissemination and transparency meet reporting requirements applicable to Financial Investment Companies, with reference to relevant aspects such as: financial and operating results, development strategies, management philosophy and objectives, shareholders' ownership and voting rights, remuneration policies applicable to management and Board of Directors, transactions involving affiliates, significant risks and uncertainties. Disclosure and presentation of financial and non-financial information should be subject to high quality financial reporting standards while dissemination must ensure equal, effective and efficient access to all external users, especially investors.

Information generated by the financial reporting system should be subject to internal audit, in an independent, objective and professional manner, to provide a reasonable assurance for management and Board of Directors that financial statements reflect, in all material aspects, a true and fair view regarding the investment companies' financial position, financial performances and the cash flows. Internal auditors should also test the efficiency and reliability of internal controls in all material aspects that may significantly influence the financial statements.

\section{f. Board of Directors' responsibilities}

Corporate governance structures should facilitate the strategic guidance of Financial Investment Companies, through effective monitoring of management by the Board of Directors. Board members must act in good faith and exercise "due diligence" in protecting all shareholders, being subject to an appropriate ethical behavior and managing key responsibilities such as:

- reviewing and guiding the overall development strategies of Financial Investment Companies, action plans, risk management policies, annual budgets and business plans;

- defining and monitoring performance objectives, in tight correlation with coordinating major investment expenditures;

- effective monitoring regarding relevant corporate governance practices, corroborated with taking measures for changes or corrections where needed;

- ensuring a transparent and formal voting system for all Board members and other persons responsible for corporate governance;

- managing and monitoring any potential conflict of interest between management, Board members and shareholders, including any misrepresentation of financial assets held by the Financial Investment Companies;

- ensuring the integrity of financial reports, including the proper functioning of internal controls, risk management processes and obedience to rules and professional standards;

\footnotetext{
${ }^{4}$ Capital market regulation requires reporting to the NSC and the market operator (BSE) any transaction invloving management, Board of Directors or other relevant persons in close relationships, investors acting in concert in relation with Financial Investment Companies and investors who purchase stock over the threshold limit of $1 \%$ of the total shares issued. In addition, the Board must report any transaction of more than EUR 50,000, involving Board members, management, employees, shareholders or other relevant persons in close relationships.
} 
- developing and implementing policies relating to employment of non-audit services provided by the external auditor, taking into account relevant ethical principles and instructions (Calder, 2008:123).

Relevant authors appreciate corporate governance codes and principles as a product that combines responses given by responsible factors as a consequence for major financial scandals, corporate economic downturn or corporate bankruptcy (Mallin, 2006). Organisations should compare their corporate governance to comply with most management practices and this may be the key to success in achieving the goals of effective governance (Ernst\&Young, 2001). Nevertheless, in the European context, some authors (Lannoo \& Khachaturyan, 2004:53) expressed the view that the Commission failed to promote the benefits of diversity in European corporate governance and to reflect existing institutional realities, trying to introduce an extended harmonization degree to meet legislative measures adopted in the U.S., due to corporate bankruptcies. Also, the European Commission failed to address U.S. corporate events in a proactive manner, which would have meant the promotion of competition legislation on corporate governance standards. Such a competition between national regulatory authorities could meet the real needs of companies, while ensuring a strong self-correcting mechanism for any incorrect or ineffective measure.

\section{Research approach and methodology. Results and discussion}

For the purpose of accomplishing the major research objective of the paper, that is to test the quality of implementation process regarding corporate governance principles applied for the Financial Investment Companies, the authors have developed a questionnaire that was addressed to management and other relevant persons holding financial reporting responsibilities. The questions were inspired from the "Comply or Explain" Statement issued by the Bucharest Stock Exchange (BSE) Market Operator in order to assure adequate implementation of corporate governance principles, as they are defined in Bucharest Stock Exchange Corporate Governance Code (March, 2010). Regarding IT governance, the questions were inspired from the "Questionnaire regarding the maturity level of control and IT governance for Romanian entities", issued by the Academy of Economic Science (March, 2010).

The research methodology was developed on the following road map:

- document adequate literature review for the purpose of identifying relevant opinions and divergences regarding the process of implementing corporate governance principles, especially for financial investment industry;

- review principles and implementing recommendations for corporate governance described in BSE Corporate Governance Code;

- develop and send a questionnaire based on the BSE "Comply or Explain" Statement, adapted for Financial Investment Companies;

- obtain and process information related Financial Investment Companies' compliance with corporate governance principles;

- test the accuracy of information by reviewing alternative sources (annual reports, official website, etc.);

- identify strengths and weaknesses in the process of implementing corporate governance principles and recommendations;

- assess the overall compliance level and assert relevant conclusions, based on previous research steps;

- establish future research, focused on recommendation pronouncements designed to overcome current deficiencies or misrepresentations related to corporate governance practices.

As a personal contribution of the authors, it is to be noticed that all questions contained in BSE "Comply or Explain" Statement were processed and adapted for specific investment operations and activities performed by all Financial Investment Companies. Moreover, the information that has 
been processed, whether displayed through "Comply or Explain" Statements or received as result of the questioning process, was tasted for accuracy, using alternative public available information (annual reports, financial statements, website specific section for investors, etc.). Another relevant contribution refers to the comparative approach adopted for all Financial Investment Companies, for the purpose of determining general conclusions regarding the overall level of compliance with corporate governance principles, by using a scoring based method. We consider these findings useful, given that some relevant deficiencies were identified. These should capture adequate attention on behalf of the management and the Board of Directors in order to improve the overall compliance level with corporate governance principles.

The research has been focused on all five Financial Investment Companies traded on Bucharest Stock Exchange (Financial Sector), namely: SIF Banat-Crisana (SIF 1), SIF Moldova (SIF 2), SIF Transilvania (SIF 3), SIF Muntenia (SIF 4), and SIF Oltenia (SIF 5). These entities operate on the Romanian capital market in double stance: issuers of securities and institutional investors (Spatacean, 2008). For the purpose of this questionnaire, SIF stands for Romanian equivalent of Financial Investment Company. A summary of the questions asked and the answers that have been processed is available in the following table:

Table no. 1

\section{Questionnaire for assessing the quality of OECD corporate governance principles' adoption by Financial Investment Companies}

\begin{tabular}{|c|c|c|c|c|}
\hline No. & Question & Yes & No & Explanations \\
\hline 1 & $\begin{array}{l}\text { Has SIF management developed Corporate } \\
\text { Governance Rules to describe the main } \\
\text { responsibilities in corporate governance: } \\
\text { transparency of investment operations, } \\
\text { corporate regulation, and protection of } \\
\text { shareholders' investments? }\end{array}$ & $\sqrt{ }$ & & $\begin{array}{l}\text { There is a public display of Corporate } \\
\text { Governance Rule, except for SIF } 2 \text {. Moreover, } \\
\text { the implementation of fundamental principles } \\
\text { is assured by compliance with applicable } \\
\text { Romanian capital market regulations. }\end{array}$ \\
\hline 2 & $\begin{array}{l}\text { Are Corporate Governance Rules } \\
\text { displayed on the SIF's official website, } \\
\text { indicating the date on which last update } \\
\text { have been provided? }\end{array}$ & $\sqrt{ }$ & & $\begin{array}{l}\text { There are Corporate Governance Rules } \\
\text { displayed on the official website of the SIF, } \\
\text { except for SIF } 2 \text {. }\end{array}$ \\
\hline 3 & $\begin{array}{l}\text { Does the Corporate Governance Rules } \\
\text { define corporate governance structures, } \\
\text { functions, authorities and responsibilities } \\
\text { of the Board of Directors and executive } \\
\text { management? }\end{array}$ & $\sqrt{ }$ & & $\begin{array}{l}\text { The functions, authorities and responsibilities } \\
\text { of persons in charge with governance and } \\
\text { management are set out CG Rules (except for } \\
\text { SIF 2), as well as in statutory documents, } \\
\text { regulations and internal procedures of SIF's. }\end{array}$ \\
\hline 4 & $\begin{array}{l}\text { Does SIF Annual Report provide a chapter } \\
\text { dedicated to corporate governance in } \\
\text { which all relevant events referring to } \\
\text { corporate governance are described, and } \\
\text { recorded during the reporting period? }\end{array}$ & $\sqrt{ }$ & & $\begin{array}{l}\text { Both the Board of Directors' report, which is } \\
\text { part of the annual report and the annual report } \\
\text { required by NSC Regulation No. } 1 / 2006 \\
\text { contain references regarding: transparency and } \\
\text { dissemination of information; shareholders' } \\
\text { rights; functions of specific Corporate } \\
\text { Governance structures (internal control, } \\
\text { internal audit, financial audit, the Audit } \\
\text { Committee). }\end{array}$ \\
\hline No. & Question & Yes & No & Explanations \\
\hline 5 & $\begin{array}{l}\text { Does SIF management respect the } \\
\text { shareholders' rights, assuring a fair } \\
\text { treatment and submitting for approval any } \\
\text { changes to the rights granted? }\end{array}$ & $\sqrt{ }$ & & $\begin{array}{l}\text { Equitable treatment for shareholders is } \\
\text { provided by the legislation framework and } \\
\text { specific regulations applicable to issuers of } \\
\text { securities (Capital Market Law and NSC } \\
\text { Regulation no. } 1 \text { / } 2006 \text { regarding issuers and } \\
\text { securities transactions). Where available, the } \\
\text { Corporate Governance Rule has established a } \\
\text { special section regarding shareholders' rights. }\end{array}$ \\
\hline
\end{tabular}




\begin{tabular}{|c|c|c|c|c|}
\hline 6 & $\begin{array}{l}\text { Has SIF's management developed and } \\
\text { proposed adequate procedures for orderly } \\
\text { and efficient GSM, but without prejudice to } \\
\text { any shareholder entitled to freely express an } \\
\text { opinion on the subjects under discussion? }\end{array}$ & $\sqrt{ }$ & & $\begin{array}{l}\text { These procedures must be explained in GSM } \\
\text { convocation notice, through the effect of the } \\
\text { provisions contained in NSC Regulation no. } 6 \text { / } \\
2009 \text { regarding the exercise of certain } \\
\text { shareholders' rights. }\end{array}$ \\
\hline 7 & $\begin{array}{l}\text { Has SIF's management disseminated in a } \\
\text { section on the official website, shareholders' } \\
\text { rights and the rules and procedures for GSM } \\
\text { participation? }\end{array}$ & $\sqrt{ }$ & & $\begin{array}{l}\text { There is a separate section where investors can } \\
\text { find GSM convocation notices, with adequate } \\
\text { disclosure of rules and procedures for } \\
\text { participation. }\end{array}$ \\
\hline \multirow[t]{7}{*}{8} & \multicolumn{4}{|c|}{$\begin{array}{l}\text { Does SIF management disseminate information on the official website on the following aspects of corporate } \\
\text { governance policy: }\end{array}$} \\
\hline & $\begin{array}{l}\text { a) a description of its corporate } \\
\text { governance structures? }\end{array}$ & $\sqrt{ }$ & & $\begin{array}{l}\text { The annual report is published on the official } \\
\text { website and contains reference to the relevant } \\
\text { structures of corporate governance. }\end{array}$ \\
\hline & b) an updated Memorandum? & $\sqrt{ }$ & & $\begin{array}{l}\text { Updated memorandum is published on the } \\
\text { official website. }\end{array}$ \\
\hline & $\begin{array}{l}\text { c) a description of internal rules of } \\
\text { operation and key issues for each } \\
\text { department or board? }\end{array}$ & $\sqrt{ }$ & & $\begin{array}{l}\text { There is a manual of rules and internal } \\
\text { procedures that describes in a reasonable } \\
\text { manner relevant tasks for each department and } \\
\text { committee. }\end{array}$ \\
\hline & $\begin{array}{l}\text { d) availability of "Comply or Explain" } \\
\text { Statement? }\end{array}$ & $\sqrt{ }$ & & $\begin{array}{l}\text { For each SIF, there is either a distinctive } \\
\text { statement, or a statement incorporated in the } \\
\text { Annual Report. }\end{array}$ \\
\hline & $\begin{array}{l}\text { e) a public list of Board of Directors' } \\
\text { members, identifying those members that } \\
\text { are independent or non-executive, } \\
\text { members of executive management and } \\
\text { members of specific committees? }\end{array}$ & $\sqrt{ }$ & & $\begin{array}{l}\text { There are references on the Board of Directors' } \\
\text { members, though without a distinct } \\
\text { delimitation of independent members and / or } \\
\text { non-executive and executives, including } \\
\text { specialized committees. }\end{array}$ \\
\hline & $\begin{array}{l}\text { f) a brief resume for each member of the } \\
\text { Board of Directors and executive } \\
\text { management? }\end{array}$ & $\sqrt{ }$ & & $\begin{array}{l}\text { A resume for each member of the Board of } \\
\text { Directors and executive management is } \\
\text { available on the official website. }\end{array}$ \\
\hline \multirow[t]{2}{*}{9} & \multicolumn{4}{|c|}{$\begin{array}{l}\text { Does SIF management publish in a distinct section on its website details regarding how General Meeting of } \\
\text { Shareholders is conducted? }\end{array}$} \\
\hline & $\begin{array}{l}\text { a) GMS convocation notice, special power } \\
\text { of attorney forms, relevant materials / } \\
\text { documents in the agenda and any other } \\
\text { information relating to items on the agenda? }\end{array}$ & $\sqrt{ }$ & & $\begin{array}{l}\text { These materials and documents are published } \\
\text { both on SIF's official website, and on market } \\
\text { operator's website (BSE), and may be } \\
\text { available to investors at request, starting with } \\
\text { publication date, at SIF's headquarters. }\end{array}$ \\
\hline \multirow[t]{3}{*}{10} & \multicolumn{4}{|c|}{$\begin{array}{l}\text { SIF management provides information in a timely manner (immediately after GSM deployment) to all } \\
\text { shareholders, through a special dedicated section on the official website: }\end{array}$} \\
\hline & a) regarding GSM decisions? & $\sqrt{ }$ & & $\begin{array}{l}\text { GSM decisions are disseminated to the } \\
\text { investors through current reports published } \\
\text { both on the official website and on BSE market } \\
\text { operator's official website (Market News } \\
\text { section). }\end{array}$ \\
\hline & $\begin{array}{l}\text { b) regarding the detailed outcome of the } \\
\text { voting process? }\end{array}$ & $\sqrt{ }$ & & $\begin{array}{l}\text { Current reports present detailed results of the } \\
\text { voting process. }\end{array}$ \\
\hline No. & Question & Yes & No & Explanations \\
\hline \multirow[t]{3}{*}{11} & \multicolumn{4}{|c|}{ Does SIF management disseminate via a special section on its own website, easily identifiable and accessible: } \\
\hline & a) current reports and communications? & $\sqrt{ }$ & & $\begin{array}{l}\text { These reports are required by the regulations } \\
\text { applicable to issuers of securities. }\end{array}$ \\
\hline & $\begin{array}{l}\text { b) financial calendar, annual reports, interim } \\
\text { reports? }\end{array}$ & $\sqrt{ }$ & & $\begin{array}{l}\text { There is a financial calendar published on the } \\
\text { official website and through a current report } \\
\text { published on BSE market operator's official } \\
\text { website (Market News section). }\end{array}$ \\
\hline
\end{tabular}




\begin{tabular}{|c|c|c|c|c|}
\hline 12 & $\begin{array}{l}\text { Has SIF's organizational structure a special } \\
\text { department or a person trained and } \\
\text { dedicated for investors' communication } \\
\text { process? }\end{array}$ & $\sqrt{ }$ & & $\begin{array}{l}\text { There are specialized departments (Corporate } \\
\text { Development and Institutional Service, } \\
\text { Shareholders' Service). There is a designated } \\
\text { contact person to maintain relationships with } \\
\text { investors and capital market institutions (BSE } \\
\text { and NSC). }\end{array}$ \\
\hline 13 & $\begin{array}{l}\text { Does the Board of Directors meet at least } \\
\text { quarterly to monitor the conduct of } \\
\text { business? }\end{array}$ & $\sqrt{ }$ & & $\begin{array}{l}\text { This provision is reflected in the Company } \\
\text { Law. The specific investment activities } \\
\text { conducted by SIF justify an adequate } \\
\text { monitoring and a high frequency of Board of } \\
\text { Directors' meetings. }\end{array}$ \\
\hline 14 & $\begin{array}{l}\text { Has SIF management implemented a set of } \\
\text { rules for conducting and reporting personal } \\
\text { transactions made on behalf of managers } \\
\text { and/or Board of Directors? }\end{array}$ & $\sqrt{ }$ & & $\begin{array}{l}\text { SIF regulations require procedures and internal } \\
\text { rules to avoid conflict of interest, including in } \\
\text { case of personal transactions made by } \\
\text { directors, management, employees or other } \\
\text { stakeholders. }\end{array}$ \\
\hline 15 & $\begin{array}{l}\text { If a member of the Board, or executive } \\
\text { management, or other relevant person is } \\
\text { involved in a transaction carried out on } \\
\text { own account, the transaction is } \\
\text { disseminated according to regulations? }\end{array}$ & $\sqrt{ }$ & & $\begin{array}{l}\text { Transactions made in the name and on behalf } \\
\text { of insiders (who have access to privileged } \\
\text { information), must be notified to the operator } \\
\text { of the regulated market (BSE), immediately, to } \\
\text { allow the market to disclose that information } \\
\text { before the next trading session. These } \\
\text { notifications are provided by current reports. }\end{array}$ \\
\hline 16 & $\begin{array}{l}\text { Does the structure of the SIF's Board of } \\
\text { Directors provide a balance between } \\
\text { executive and non-executive members, } \\
\text { and especially non-executive independent } \\
\text { directors, so that no person or group of } \\
\text { individuals can dominate the decision- } \\
\text { making process? }\end{array}$ & $\sqrt{ }$ & & $\begin{array}{l}\text { For SIF 1, the projected structure of the Board } \\
\text { includes a president who also holds the CEO } \\
\text { position, a vice president (independent non- } \\
\text { executive director) and three independent non- } \\
\text { executive directors (two of whom form the } \\
\text { Audit Committee). For SIF } 3 \text { all members are } \\
\text { non-executive and for SIF } 5 \text { there are two } \\
\text { executive members. For the remaining SIFs } \\
\text { there is no adequate presentation regarding } \\
\text { the distinction between executive and non- } \\
\text { executive members. }\end{array}$ \\
\hline 17 & $\begin{array}{l}\text { During its missions, is the Board } \\
\text { supported by committees or advisory } \\
\text { commissions for the purpose of } \\
\text { monitoring specific topics, and of } \\
\text { providing qualified assistance / advice on } \\
\text { these topics? }\end{array}$ & $\sqrt{ }$ & & $\begin{array}{l}\text { The Board receives valuable support from the } \\
\text { Audit Committee, which provides consultancy } \\
\text { / advice on issues related to supervision of } \\
\text { financial reporting process. A notable } \\
\text { exception regards SIF Oltenia, where no } \\
\text { committees are organized, due to lack of } \\
\text { independent directors. }\end{array}$ \\
\hline 18 & $\begin{array}{l}\text { Shall the committees / advisory } \\
\text { commissions submit periodic activity } \\
\text { reports addressed to the Board on the } \\
\text { subjects entrusted? }\end{array}$ & $\sqrt{ }$ & & $\begin{array}{l}\text { Audit Committee prepares periodic reports on } \\
\text { the fulfillment of SIF's financial reporting } \\
\text { obligations, risk assessment and } \\
\text { implementation of relevant internal controls } \\
\text { (except for SIF 5). }\end{array}$ \\
\hline 19 & $\begin{array}{l}\text { Are there written procedures for assessing } \\
\text { the independence of non-executive } \\
\text { members of the Board of Directors? }\end{array}$ & $\sqrt{ }$ & & $\begin{array}{l}\text { These procedures are issued pursuant to } \\
\text { statutory provisions regarding the requirements } \\
\text { to be met by members of the Board. }\end{array}$ \\
\hline 20 & $\begin{array}{l}\text { Do members of the Board permanently } \\
\text { improve their knowledge through } \\
\text { professional training in CG? }\end{array}$ & $\sqrt{ }$ & & There is an ongoing concern in this regard. \\
\hline No. & Question & Yes & No & Explanations \\
\hline 21 & $\begin{array}{l}\text { Is the election process of SIF's Board } \\
\text { members based on a transparent procedure } \\
\text { (e.g., objective personal skills, experience } \\
\text { and professional qualifications)? }\end{array}$ & $\sqrt{ }$ & & $\begin{array}{l}\text { A transparent procedure for election Board } \\
\text { members is provided by regulations applicable } \\
\text { to issuers of securities. A minimum } \\
\text { requirement is to provide shareholders a } \\
\text { resume stating qualifications and relevant } \\
\text { experience to access a mandate. }\end{array}$ \\
\hline
\end{tabular}




\begin{tabular}{|c|c|c|c|c|}
\hline 22 & $\begin{array}{l}\text { Is there a Nomination Committee in the } \\
\text { SIF's organizational structure? }\end{array}$ & & $\sqrt{ }$ & $\begin{array}{l}\text { There is no Nomination Committee. The } \\
\text { eligibility criteria are established by the } \\
\text { company's memorandum and specific NSC } \\
\text { regulations. }\end{array}$ \\
\hline 23 & $\begin{array}{l}\text { Is there a Remuneration Committee } \\
\text { consisting exclusively of non-executive } \\
\text { directors? }\end{array}$ & & $\sqrt{ }$ & $\begin{array}{l}\text { There is no Remuneration Committee. The } \\
\text { remuneration policy for management and the } \\
\text { Board is approved by GSM. The Board } \\
\text { analyzes the remuneration policy on an } \\
\text { annual basis. }\end{array}$ \\
\hline 24 & $\begin{array}{l}\text { Does the Board review at least on a yearly } \\
\text { basis: the need of setting up a } \\
\text { Remuneration Committee, or if one exists, } \\
\text { the remuneration policy for executive } \\
\text { directors? }\end{array}$ & $\sqrt{ }$ & & $\begin{array}{l}\text { There are reports that could argue the } \\
\text { establishment of a Remuneration Committee. }\end{array}$ \\
\hline 25 & $\begin{array}{l}\text { Is the remuneration policy approved by } \\
\text { shareholders? }\end{array}$ & & $\sqrt{ }$ & $\begin{array}{l}\text { GSM decisions concern only the amount of } \\
\text { allowance owed to Board of Directors and } \\
\text { management, while the authority regarding } \\
\text { employee remuneration policy is allocated to } \\
\text { CEO. For SIF } 1 \text { and SIF } 3 \text { there are specific } \\
\text { references regarding remuneration policy for } \\
\text { management and Board of Directors' in the } \\
\text { CG Rule or in the Company Memorandum. }\end{array}$ \\
\hline 26 & $\begin{array}{l}\text { Is the remuneration policy described in } \\
\text { SIF's memorandum / Rules of Corporate } \\
\text { Governance? }\end{array}$ & & $\sqrt{ }$ & $\begin{array}{l}\text { There is no stated policy on employees' } \\
\text { remuneration. There are no performance } \\
\text { objectives and valuation criteria, as a } \\
\text { fundament for the remuneration policy. }\end{array}$ \\
\hline \multirow[t]{3}{*}{27} & \multicolumn{4}{|c|}{$\begin{array}{l}\text { Does SIF management disseminate in English, or another foreign language, information that is subject to } \\
\text { reporting requirements: }\end{array}$} \\
\hline & $\begin{array}{l}\text { a) periodic disclosure of financial } \\
\text { information? }\end{array}$ & $\sqrt{ }$ & & $\begin{array}{l}\text { SIF official website contains a proper English } \\
\text { section, to disseminate information on a } \\
\text { regularly basis. }\end{array}$ \\
\hline & $\begin{array}{l}\text { b) permanent disclosure of financial } \\
\text { information? }\end{array}$ & $\sqrt{ }$ & & $\begin{array}{l}\text { SIF official website contains a proper English } \\
\text { section, to disseminate information on a } \\
\text { permanent basis. }\end{array}$ \\
\hline 28 & $\begin{array}{l}\text { Does SIF management prepare and } \\
\text { disseminate financial reporting in } \\
\text { compliance with IFRS? }\end{array}$ & $\sqrt{ }$ & & $\begin{array}{l}\text { Consolidated financial statements are prepared } \\
\text { in accordance with IFRS adopted by the } \\
\text { European Union, since the reporting period } \\
\text { ending at } 31.12 .2007 \text {. These financial } \\
\text { statements are not audited and the management } \\
\text { declined responsibility for their accuracy. For } \\
\text { SIF } 1 \text { and SIF } 2 \text {, no } 2010 \text { consolidated } \\
\text { financial statements according to IFRS were } \\
\text { available, whereas for SIF } 5 \text { the consolidated } \\
\text { financial statements were not audited. }\end{array}$ \\
\hline 29 & $\begin{array}{l}\text { Does SIF management promote, at least } \\
\text { once a year, meetings with financial } \\
\text { analysts, brokers, investment advisors, } \\
\text { rating agencies and other capital market } \\
\text { specialists, to present financial elements } \\
\text { relevant investment decisions? }\end{array}$ & $\sqrt{ }$ & & $\begin{array}{l}\text { There is interest for such events. SIF Banat } \\
\text { Crisana has a tradition of involvement in the } \\
\text { organization of scientific meetings on topics } \\
\text { subordinated to capital market area. }\end{array}$ \\
\hline No. & Question & Yes & No & Explanations \\
\hline 30 & $\begin{array}{l}\text { Does SIF organizational structure have an } \\
\text { Audit Committee? }\end{array}$ & $\sqrt{ }$ & & $\begin{array}{l}\text { Within Board's structure, an Audit Committee } \\
\text { operates, except for SIF 5. Compulsory } \\
\text { establishment of the Audit Committee stems } \\
\text { from national law (Company Law and } \\
\text { Statutory Audit Law) but it also promoted by } \\
\text { NSC regulations (Disposition of Measures no. } \\
\text { 15/23.09.2009). }\end{array}$ \\
\hline
\end{tabular}




\begin{tabular}{|c|c|c|c|c|}
\hline 31 & $\begin{array}{l}\text { Board of Directors or Audit Committee, as } \\
\text { appropriate, regularly review the } \\
\text { effectiveness of financial reporting } \\
\text { process, internal control and risk } \\
\text { management system implemented for } \\
\text { SIF's investment operations? }\end{array}$ & $\sqrt{ }$ & & $\begin{array}{l}\text { The Audit Committee assists the Board in } \\
\text { discharging its responsibilities regarding } \\
\text { financial reporting, internal control and risk } \\
\text { management. The Audit Committee supports } \\
\text { the Board in monitoring the credibility and } \\
\text { integrity of reported financial information, } \\
\text { especially by reviewing the relevance and } \\
\text { consistency of the applicable accounting } \\
\text { standards and practices. }\end{array}$ \\
\hline 32 & $\begin{array}{l}\text { Is the Audit Committee composed } \\
\text { exclusively of non-executive directors and } \\
\text { does it have a sufficient number of } \\
\text { independent directors? }\end{array}$ & $\sqrt{ }$ & & $\begin{array}{l}\text { The Audit Committee is composed exclusively } \\
\text { of non-executive directors (SIF Banat Crisana, } \\
\text { SIF Transilvania) and has an independent non- } \\
\text { executive director (SIF Transilvania). } \\
\text { Members of the Audit Committee have the } \\
\text { experience and qualifications required for the } \\
\text { application of accounting and auditing } \\
\text { principles. }\end{array}$ \\
\hline 33 & $\begin{array}{l}\text { Does the Audit Committee meet at least } \\
\text { two times a year, and are these sessions } \\
\text { dedicated to the preparation and } \\
\text { dissemination of financial reports to } \\
\text { shareholders and the public? }\end{array}$ & $\sqrt{ }$ & & $\begin{array}{l}\text { Audit Committee is meeting in the } \\
\text { composition of the Board, with a maximum } \\
\text { quarterly frequency. }\end{array}$ \\
\hline 34 & $\begin{array}{l}\text { Does Audit Committee issue } \\
\text { recommendations to the Board regarding } \\
\text { the selection, appointment, re-appointment } \\
\text { and replacement of the financial auditor, } \\
\text { including remuneration terms and } \\
\text { conditions? }\end{array}$ & $\sqrt{ }$ & & $\begin{array}{l}\text { These responsibilities are set out by regulations } \\
\text { applied to SIF's operations and are detailed in } \\
\text { the manual of rules and internal procedures. }\end{array}$ \\
\hline 35 & $\begin{array}{l}\text { Has the Board adopted an internal } \\
\text { procedure for identification and } \\
\text { appropriate resolution of conflicts of } \\
\text { interest? }\end{array}$ & $\sqrt{ }$ & & $\begin{array}{l}\text { According to secondary legislation applicable } \\
\text { to SIF's investment operations (NSC } \\
\text { Regulation no. 15/2004), the management } \\
\text { monitors operational procedures implemented } \\
\text { to avoid conflicts of interest arising from } \\
\text { financial asset management activities, personal } \\
\text { transactions that involve employees, or } \\
\text { transactions between SIF and companies that } \\
\text { have established prior business relationship. }\end{array}$ \\
\hline 36 & $\begin{array}{l}\text { Is the Board informed in real time upon } \\
\text { conflicts of interest affecting some } \\
\text { members and if so, do those members } \\
\text { refrain from debate and voting on matters } \\
\text { in question, in accordance with legal } \\
\text { provisions? }\end{array}$ & $\sqrt{ }$ & & $\begin{array}{l}\text { To the extent that the Board of Directors is } \\
\text { informed upon potential conflicts of interest, } \\
\text { the members concerned shall refrain from } \\
\text { voting. However, there is no register of } \\
\text { conflicts of interest and timely information } \\
\text { could be affected. }\end{array}$ \\
\hline 37 & $\begin{array}{l}\text { Has the Board adopted specific procedures } \\
\text { to identify transactions that involve } \\
\text { insiders or related parties? (e.g. criteria } \\
\text { for identifying significant transactions, } \\
\text { transparency and objectivity criteria, etc.). }\end{array}$ & $\sqrt{ }$ & & $\begin{array}{l}\text { There are procedures for identifying and } \\
\text { reporting to NSC transactions that involve } \\
\text { insiders or related parties. Current reports } \\
\text { covering this type of transactions or notices } \\
\text { regarding the overcome of } 1 \% \text { ownership } \\
\text { threshold are made available both on the } \\
\text { official website and on BSE market operator's } \\
\text { official website (Market News section). }\end{array}$ \\
\hline No. & Question & Yes & No & Explanations \\
\hline 38 & $\begin{array}{l}\text { Has the Board adopted adequate } \\
\text { procedures regarding internal circulation } \\
\text { and disclosure to third parties of } \\
\text { documents and relevant information, with } \\
\text { particular importance of information that } \\
\text { can influence the market price of } \\
\text { marketable financial instruments issued by }\end{array}$ & $\sqrt{ }$ & & $\begin{array}{l}\text { There is an internal timetable of documents } \\
\text { and relevant information. There are } \\
\text { implemented internal procedures for } \\
\text { identifying information subject to periodic and } \\
\text { current reports to BSE market operator: } \\
\text { - inside information; } \\
\text { - events that can produce significant changes in }\end{array}$ \\
\hline
\end{tabular}




\begin{tabular}{|c|c|c|c|c|}
\hline & SIF? & & & $\begin{array}{l}\text { share price; } \\
\text { - quarterly, biannual and annual reports } \\
\text { - supplementary reports and other reports. }\end{array}$ \\
\hline 39 & $\begin{array}{l}\text { Are IT governance efforts integrated within } \\
\text { corporate governance structures and } \\
\text { principles applied to SIF? }\end{array}$ & $\sqrt{ }$ & & $\begin{array}{l}\text { There are rigorous concerns from SIF } \\
\text { management to ensure a smooth integration of } \\
\text { IT governance in the corporate governance } \\
\text { process. These concerns are fueled by needs, } \\
\text { such as: credibility and transparency of } \\
\text { financial reporting, safety of financial assets } \\
\text { and security of IT technologies that are being } \\
\text { exploited. }\end{array}$ \\
\hline 40 & $\begin{array}{l}\text { Have been established IT performance } \\
\text { indicators? }\end{array}$ & $\sqrt{ }$ & & $\begin{array}{l}\text { The IT performance indicators' system aims } \\
\text { at relevant coordinates, such as: } \\
\text { - improving IT security by reducing } \\
\text { vulnerabilities and threats associated with } \\
\text { information systems; } \\
\text { - segregation of duties within the IT system; } \\
\text { - providing back-up systems for information } \\
\text { storage and disaster data recovery. } \\
\text { - increasing the speed of execution and } \\
\text { improving the efficiency that transactions are } \\
\text { processed with; } \\
\text { - ensuring an adequate level of flexibility and } \\
\text { adaptability of IT systems; } \\
\text { - optimizing cost-benefit parameters for } \\
\text { information obtained / reported. }\end{array}$ \\
\hline 41 & $\begin{array}{l}\text { Is there a periodic assessment and } \\
\text { monitoring of IT risks? }\end{array}$ & $\sqrt{ }$ & & $\begin{array}{l}\text { IT risk assessment and monitoring operations } \\
\text { is an essential component for the strategy of } \\
\text { implementing IT audit, provided by certified } \\
\text { ISACA auditors. Mandatory IT audit for } \\
\text { information systems used by regulated and } \\
\text { supervised entities that operate in the capital } \\
\text { market (including SIF) is imposed by an NSC } \\
\text { regulation. }\end{array}$ \\
\hline 42 & $\begin{array}{l}\text { Does SIF management engage in activities } \\
\text { regarding Environmental and Social } \\
\text { Responsibility? }\end{array}$ & & $\sqrt{ }$ & $\begin{array}{l}\text { Due to the specific nature of portfolio } \\
\text { management activities, there is no concern on } \\
\text { behalf of SIF's management regarding the } \\
\text { impact of core business on the environment. } \\
\text { According to Corporate Governance Rules that } \\
\text { have been reviewed, social responsibility may } \\
\text { be approached as a concern in terms of } \\
\text { conferences and scientific manifestations that } \\
\text { have been organized, the safety of jobs } \\
\text { provided for employees, the environmental } \\
\text { management policy and social contributions } \\
\text { that are been paid to state budget. }\end{array}$ \\
\hline
\end{tabular}

The objectives of this questionnaire are aimed at assessing how Financial Investment Companies implement and apply corporate governance principles agreed by the OECD, based on a methodology focused on a qualitative assessment. A summary of relevant findings may be structured as it follows:

a) Findings that sustain adequate implementation and application of corporate governance principles. These findings are suggested by the positive answer received for the majority of questions that have been addressed. From a total number of 42 questions, 37 questions have received positive answers $(88.10 \%)$, reflecting a satisfactory level of compliance with relevant corporate governance principles and recommendations. Among these, we find relevant the following: 
- the annual report contains references on transparency, shareholder rights and functions of different corporate governance specific structures;

- there are special statements regarding "Comply or Explain" principle, given that listed companies should issue such document, according to BSE Corporate Governance Code. This statement is either a sole document (SIF Banat-Crisana, SIF Muntenia) or contained in the 2010 Annual Report (SIF Moldova, SIF Transilvania and SIF Oltenia);

- there are distinctive Corporate Governance Rules to describe the main responsibilities in corporate governance, the relevant corporate governance structures, functions, and authorities;

- there is fair treatment and transparency in relation with shareholders are provided in addition to laws applicable to issuers of securities;

- there are specialized departments are formed for the purpose of maintaining relationships with investors and capital market institutions;

- there is a sufficient number of independent and non-executive members, so that decisionmaking process can not be dominated;

- the Audit Committee assists the Board in discharging its responsibilities in financial reporting, internal control and risk management;

- management monitors the operating procedures implemented to avoid conflicts of interest arising from portfolio management activities and operations;

- there is a rigorous concern for integrating IT governance in the corporate governance process.

b) Findings that suggest deficiencies in the process of implementing corporate governance principles. These findings are suggested by the negative answer received for some of the questions that have been addressed. From a total number of 42 questions, 5 questions have received negative answers $(11.90 \%)$, reflecting areas that need to receive special treatment and a future adequate monitoring. Among these, we find relevant the following:

- there is no nomination or remuneration committee. Specific functions of these committees have been allocated to other relevant corporate governance structures or functions, such as: management, internal audit, internal control, risk management, etc.;

- there is no adequate presentation regarding the distinction between executive and nonexecutive members for the Board of Directors, except for SIF Transilvania. In conclusion, we could not obtain reasonable assurance regarding a sufficient number of independent members, so that no person or group of individuals can dominate the decision-making process;

- there is no approved and publicly stated policy on employees' remuneration, no performance targets, no criteria for performance valuation and no monitoring standards.

Another relevant coordinate of the research approach had a quantitative feature, and was based on determining a score for each Financial Investment Company. Each entity's score is the result of a complex valuation regarding different policies and practices and represents rather an expression of current corporate governance standards than an opinion upon financial and commercial performances (Ghita et al., 2009: 93).

The following table highlights the questionnaire's structure in relation to relevant corporate governance areas that have been investigated. It also contains the scores assigned for each Financial Investment Company, in order to distinguish between those entities who benefit from better compliance with corporate governance principles and those who need to improve in a significant manner the current standards, policies and practices. The general score was assigned by summing 
all score functions determined for each area of investigation ${ }^{5}$, adjusted by the weight of each area in total.

Table no. 2

\section{Quantitative assessment of OECD corporate governance principles' adoption by Financial} Investment Companies

\begin{tabular}{|c|c|c|c|c|c|c|c|c|}
\hline \multirow[t]{2}{*}{ Investigation Area } & \multirow{2}{*}{$\begin{array}{c}\text { No. of } \\
\text { questions }\end{array}$} & \multirow{2}{*}{$\begin{array}{c}\text { Importance } \\
\text { weight } \\
(\%)\end{array}$} & \multirow{2}{*}{$\begin{array}{l}\text { Maximum } \\
\text { score } \\
\text { (points) }\end{array}$} & \multicolumn{5}{|c|}{ Entity's score (points) } \\
\hline & & & & SIF 1 & SIF 2 & SIF 3 & SIF 4 & SIF 5 \\
\hline $\begin{array}{l}\text { CG Internal Rules \& } \\
\text { Procedures } \\
(\text { q. } 1,2,3,6,14,19,21,35 \text {, } \\
\text { 36, 37, 38) }\end{array}$ & 11 & 26.19 & 33 & 24 & 22 & 25 & 25 & 23 \\
\hline $\begin{array}{l}\text { CG Disclosures \& } \\
\text { Presentations } \\
(\mathrm{q} .4,7,8,9,10,11,15,26)\end{array}$ & 8 & 19.05 & 24 & 22 & 20 & 22 & 12 & 20 \\
\hline $\begin{array}{l}\text { Advisory Committees and } \\
\text { Commissions } \\
\text { (q. } 17,18,22,23,30,32,33 \text {, } \\
\text { 34) }\end{array}$ & 8 & 19.05 & 24 & 14 & 14 & 15 & 14 & 3 \\
\hline $\begin{array}{l}\text { Board of Directors' } \\
\text { Responsibilities } \\
\text { (q. 13, 20, 24, 31) }\end{array}$ & 4 & 9.52 & 12 & 8 & 8 & 9 & 5 & 8 \\
\hline $\begin{array}{l}\text { IT Governance } \\
\text { (q. 39, 40, 41) }\end{array}$ & 3 & 7.15 & 9 & 3 & 3 & 3 & 3 & 3 \\
\hline $\begin{array}{l}\text { Financial Reporting Process } \\
(\mathrm{q} .27,28)\end{array}$ & 2 & 4.76 & 6 & 4 & 4 & 6 & 3 & 5 \\
\hline $\begin{array}{l}\text { Shareholders' Rights \& } \\
\text { Approvals } \\
(\mathrm{q} .5,25)\end{array}$ & 2 & 4.76 & 6 & 5 & 4 & 5 & 4 & 4 \\
\hline $\begin{array}{l}\text { Investors' and Community } \\
\text { Communication Process (q. } \\
12,29 \text { ) }\end{array}$ & 2 & 4.76 & 6 & 6 & 6 & 3 & 5 & 3 \\
\hline $\begin{array}{l}\text { Control Balance } \\
\text { (q. 16) }\end{array}$ & 1 & 2.38 & 3 & 1 & 1 & 2 & 1 & 1 \\
\hline $\begin{array}{l}\text { Environmental and Social } \\
\text { Responsibility } \\
\text { (q. 42) }\end{array}$ & 1 & 2.38 & 3 & 1 & 1 & 1 & 1 & 1 \\
\hline TOTAL & 42 & 100.00 & 20.57 & 14.88 & 13.93 & 15.41 & 12.81 & 12.00 \\
\hline
\end{tabular}

In a general approach, the figures obtained reflect a good compliance with corporate governance principles and recommendations. The average score obtained for the five Financial Investment Companies that have been analyzed is 13.81 points from a maximum of 20.57 points. SIF Banat Crisana, SIF Moldova and SIF Transilvania marked scores above the average reflecting a better compliance level, whereas SIF Muntenia and SIF Muntenia marked scores bellow the average, suggesting a need of significant improvement related to current practices, rules and procedures.

Taking into account the general scores attributed to each entity and the balance between positive and negative answers (Strengths vs. Weaknesses), the authors declare themselves satisfied with the quality of the adoption process regarding generally accepted corporate governance principles and recommendations in case of Financial Investment Companies. Futures research

\footnotetext{
${ }^{5}$ To convert the qualitative component of each investigated area of corporate governance into quantitative component, the authors used a skeptical professional judgment, as follows: 3 points granted for "very good compliance", 2 points granted for "good compliance", 1 point granted for "satisfactory compliance" and 0 points granted for "unsatisfactory compliance".
} 
activities may be focused on monitoring whether deficiencies that have been identified are properly handled by management and Board of Directors inside Financial Investment Companies. Moreover, a future study may concern the quality of corporate governance principles' implementation for Romanian industry of mutual funds, another distinctive category of institutional investors.

\section{Conclusion}

In a general approach, for the entities whose securities are admitted to trading on a regulated capital market to take advantage of stability in terms of attracting funding, specific corporate governance processes should be characterized by a high degree of transparency, fairness and credibility in relation to shareholder, based on internationally accepted principles. For Financial Investment Companies, corporate governance implies well-established relationships between management, the Board of Directors and shareholders, providing a favorable climate for accomplishing investment objectives, identifying adequate methods and instruments of achieving them and monitoring portfolio performances. Appropriate levels of transparency in presentation and disclosure of information, effective communication and appropriate measures and responsibilities are essential to ensure good corporate governance, especially in the financial investment industry.

\section{References}

1. Anand S., 2007. Essentials of Corporate Governance, John Wiley\&Sons Inc.

2. Calder A., 2008. Corporate Governance. A Practical Guide to the Legal Frameworks and International Codes of Practice, MPG Books Ltd., Bodmin, Cornwall

3. Danescu T., Spatacean O., 2008. Corporate governance - principles applicable to entities listed on a regulated capital market, Financial Audit Journal, no. 8, pp. 31-37

4. Dragomir V., 2010. Corporate governance and Sustenability in European Union, Economica Publishing House, Bucharest

5. Ghidiu I., Danescu T., 2010. Information society - sustainable development premise in a competitive economy, Studia Universitatis „Petru Maior”- Series Oeconomica

6. Ghiţă M., Briciu S., Sas F., Ghiță R., Tamaş A. S., Dobra I. B., 2009. Corporate Governance and Internal Audit, Aeternitas Publishing House, Alba Iulia

7. Hellman N., 2005. Can we expect institutional investors to improve corporate governance?, Scandinavian Journal of Management, 21, pp. 293-327

8. Lannoo K., Khachaturyan A., 2004. Reform of Corporate Governance in the EU, European Business Organization Law Review, 5, pp. 37-60

9. Lutgart Van den Berghe, 2002. Corporate Governance in a Globalising World: Convergence or Divergence? A European Perspective, Kluwer Academic Publishers

10. Mallin C.A., 2006. Handbook On International Corporate Governance, Edward Elgar Publishing Limited, U.K.

11. Morariu A., Suciu Gh., Stoian F., 2008. Internal Audit and Corporate Governance, Universitara Publishing House, Bucharest

12. Onofrei M., 2009. Financial Corporate Governance, Wolters Kluwer Publishing House, Bucharest

13. Solomon J., Solomon A., 2004. Corporate Governance and Accountability, John Wiley\&Sons Ltd.

14. Spatacean O., 2008. The implications of the international financial crisis on institutional investors - Financial Investment Companies, Oeconomica Magazine, „Petru Maior” University

15. Ernst\&Young, 2001. Quality in Everything We Do - Achieving Effective Corporate Governance, Assurance and Advisory Business Services, London

16. www.banat-crisana.com, www.sifm.ro, www.transif.ro, www.sifmuntenia.ro, www.sifolt.ro, www.bvb.ro. 